\title{
Body-worn cameras and transparency: Experimental evidence of inconsistency in police executive decision-making *
}

\author{
Brandon Tregle University of Nebraska Omaha \\ Justin Nix University of Nebraska Omaha \\ Justin T. Pickett University at Albany, SUNY
}

\begin{abstract}
Body-worn cameras (BWC) have diffused rapidly throughout policing as a means of promoting transparency and accountability. Yet, whether to release BWC footage to the public remains largely up to the discretion of police executives, and we know little about how they interpret and respond to BWC footage - particularly footage involving critical incidents. We asked a nationally representative sample of police executives $(\mathrm{N}=476)$ how supportive they were of legislation that would mandate releasing BWC footage upon request as public information, and presented them with an experimental vignette about BWC capturing one of their officers fatally shooting an [armed/unarmed] [Black/White] suspect. Results indicated inconsistency in executives' attiudes and decision-making: (1) less than one-third of executives supported such legislation, (2) suspect race and armed/unarmed status shaped how executives felt media would cover the incident and whether they would state publicly that the shooting was justified, and (3) agency size conditioned the effects of armed/unarmed status on executives' perceptions.
\end{abstract}

Keywords: body-worn cameras, transparency, experiment, media, officer-involved shootings

\section{Introduction}

As video recording technology evolves and diffuses throughout society, officer involved shootings (OIS) are more likely to be captured on camera. Approximately $48 \%$ of all law enforcement agencies utilize body worn cameras to record interactions between officers and citizens (Hyland, 2018). In addition, over 80\% of U.S. adults have smartphones capable of recording (Pew Research Center, 2019). Video surveillance of police officers has become part of a larger push for accountability and transparency. When controversial OIS are captured on camera, executives face a difficult decision: they must balance the integrity of the ongoing investigation against public demand for release of the footage, among other calls for transparency. They may similarly be concerned with the optics of the video, and whether the public and/or media might misinterpret or overreact to the footage (Nix \& Pickett, 2017). The widespread use of video recording technology means that police executives are faced with these difficult decisions more frequently than ever before.

"Forthcoming at fustice Quarterly (accepted 9/3/2020). We appreciate Brad Campbell's help in conceiving the original idea for this project, and in developing an earlier version of the vignette, which was administered to a different sample in 2016. Replication files are available on the second author's Github account (http://github.com/jnixy). Corresponding author: jnix@ unomaha.edu. NOTE: this is the authors' post-print ( $\underline{\text { CC-BY-NC-ND 4.0 }) . ~}$ 
Using footage of a critical policing incident, such as a shooting, to determine what happened is not easy. Interpretations are inherently subjective (Mourtgos \& Adams, 2019), and police executives are likely to consider this when communicating with the public in the aftermath. Unfortunately, we know very little about police executives' views about transparency. We do not know whether they generally support releasing BWC footage to the public. We do not know whether they believe certain situational features of a critical incident increase the likelihood of misinterpretations or negative publicity. We do not know whether features of the situation influence their willingness to release BWC footage, provide details about the suspect and officer involved, meet with the family of the deceased, or answer questions about whether the shooting was justified. Finally, we do not know how agency characteristics affect police executives' decisions about transparency.

The goal of the current study is to begin to provide answers to these questions by adding to a growing body of research on police executives' perceptions of new tactics, strategies, and public-relations issues. For example, recent research has explored their views on organizational priorities (Matusiak, 2019), militarization (Turner \& Fox, 2019), organizational justice (Wolfe et al., 2018), and evidence-based practices (Telep \& Winegar, 2016). Using experimental data from a recent, nationally representative survey of police executives in the United States, we analyze how agency characteristics and situational factors jointly influence police executives' expectations for how the media will cover OISs and their transparency-related decision-making. We also examine police executives' global support for releasing BWC footage.

\section{Body-Worn Cameras in Policing: Effects and Public Support}

When 4,000 law enforcement agencies were asked as part of the 2016 Law Enforcement Management and Administrative Statistics (LEMAS) Survey why they acquired BWCs, approximately three-fourths cited the following reasons: reduce civilian complaints, improve evidence quality, reduce agency liability, and improve officer/agency accountability. Other common responses included to improve community perceptions (57\%) and to simplify incident review (50\%). On the flipside, $68 \%$ of agencies that had not adopted BWCs cited concerns about being bombarded with public records requests and the cost associated with video redactions (Hyland, 2018). These straightforward responses clearly indicated that agencies have had to weigh potential gains in transparency and accountability against the tangible costs associated with outfitting their officers with BWCs. Fortunately, unlike past technological innovations in policing, the dif- 
fusion of BWCs has been accompanied by a wave of evaluation research that has aided our understanding of the effects of BWCs on policing.

To date, approximately 70 empirical studies have been released which provide evidence regarding the effects of BWCs on officers' behaviors and attitudes, citizens' behaviors and attitudes, investigations, and various organizational outcomes. On the one hand, survey research has generally found that officers are receptive to BWCs (Gaub et al., 2018; W. Jennings et al., 2014; White et al., 2018) because they see BWCs as a form of protection against citizen allegations of misconduct (Goetschel \& Peha, 2017; Owens \& Finn, 2018; Pelfrey Jr. \& Keener, 2016). Indeed, with a few exceptions (Ariel et al., 2015; White et al., 2018), most studies have demonstrated that officers wearing BWCs received significantly fewer complaints than officers not wearing them (Ariel et al., 2017; Braga et al., 2018; Katz et al., 2014). On the other hand, community surveys indicate that the public is supportive of agencies outfitting their officers with BWCs because they see it as a way to hold police more accountable for disparities in stops, arrests, and uses of force (Sousa et al., 2018; Todak et al., 2018). Interestingly, then, both parties see BWCs as a way to hold the other more accountable (White \& Malm, 2020). Yet, evidence concerning the effects of BWCs on organizational outcomes (e.g., policies, training, accountability) is scant. Based on their review of the evidence, Lum et al. (2019) concluded that "[e]xpectations... surrounding BWCs among police leaders and citizens have not yet been realized by and large in the ways anticipated by each" (p. 93).

Surprisingly, we know comparatively little about the effects of BWCs on police organizational processes and after-the-fact decision making on issues pertaining to BWCs. For example, the 2016 LEMAS survey suggested approximately $14 \%$ of agencies using BWCs did not have a written policy pertaining to BWCs, and even among those that did, just 54\% included language stipulating when raw footage of incidents can be publicly released (Hyland, 2018). Meanwhile, the National Conference of State Legislatures indicates that just 23 states and the Districts of Columbia have legislation pertaining to BWC data and open records laws. Often, these laws allow agencies to exempt themselves from FOIA requests if footage relates to ongoing investigations. ${ }^{1}$ Thus, in many jurisdictions, what agencies do with BWC footage is a matter of executive discretion. Agencies can take great strides (or endure great setbacks) in transparency following critical incidents like OIS being recorded by BWCs. Quickly releasing footage might be wise from a public relations standpoint, but might be challenging due to the need to make redactions and protect the integrity of ongoing investigations. The alternative is to delay or refuse to release footage, which

\footnotetext{
${ }^{1}$ See http://www.ncsl.org/research/civil-and-criminal-justice/body-worn-cameras-interactive-graphic.aspx\#/.
} 
might be interpreted by the community as a sign the agency is hiding something egregious - as was the case in Chicago following the shooting of Laquan McDonald (Husain, 2019). Unfortunately, we lack a clear understanding of what influences executive decision making in instances like these, and about whether decisions vary across agency contexts.

\section{Police Executives' Decisions About Transparency}

Theoretically, both agency characteristics and the specific situational features of a BWC-recorded OIS may be associated with police executives' anticipation of media hostility and willingness to communicate with members of the community - including the family of the deceased. First, it seems likely that the size of the agency involved in the shooting will be relevant, as BWCs have diffused more rapidly throughout larger agencies, which are responsible for policing large cities (Hyland, 2018). Large cities are home to a disproportionate share of Americans, as well as serious index crime, and decades of empirical evidence indicates that police shootings are correlated with community violence (Jacobs \& O’Brien, 1998; Klinger et al., 2016; Liska \& Yu, 1992; MacDonald et al., 2001; Sorensen et al., 1993). Thus, in large cities, the sheer number of police-citizen interactions that occur on a day-to-day basis far exceed those that occur in smaller jurisdictions - and they are more likely to be recorded by officers' BWCs. Because large agencies have led the way in terms of adopting BWCs, it is likely that they have more experience dealing with controversial incidents being recorded. Indeed, they may even have clearer policies in place for how to proceed in the aftermath of such incidents (White \& Fradella, 2017; White \& Malm, 2020). Because of their greater experience with BWC, our first hypothesis (H1) is that executives serving large agencies (defined as those employing $100+$ sworn officers) will be more supportive of legislatively mandated transparency with the public following a controversial BWC-captured OIS.

Second, at least two situational variables are likely salient to police executives as they decide what steps to take in the aftermath of such an event: the race of the citizen involved and whether he or she was armed. In recent years there has been substantial academic and political debate over the (implicit or explicit) role of citizen race in officers' decision-making - especially regarding the use of deadly force (Edwards et al., 2019; Goff et al., 2016; James et al., 2016; Nix et al., 2017; Ross, 2015). On the one hand, the findings from many prior studies (e.g., Fryer Jr, 2016) are uninterpretable because they condition on mediator variables (stops, arrests, or fatal shootings), which biases the relationship between citizen race 
and outcomes of interest (Knox \& Mummolo, 2020; Ross et al., 2018). Yet on the other hand, studies that calculate police-involved fatality rates for groups based on their share of the general population may not be making "apples to apples" comparisons, and many factors in addition to police decision-making could be contributing to observed disparities (Edwards et al., 2019; Schwartz \& Jahn, 2020). The problem is that police administrative data only includes citizens who were stopped, but to test for racial bias, researchers also need to know who police observed and chose not to stop (Alpert et al., 2005; Goldstein, 1960; Knox \& Mummolo, 2020). Ultimately, large-scale comparative BWC data would help researchers estimate both encounter rates and disparities in shootings, less lethal force, or other outcomes such as verbal disrespect (Voigt et al., 2017).

Media scrutiny and public outrage stemming from several police-involved deaths of unarmed Black men has led to formation of advocacy groups like Black Lives Matter, the first Presidential Task Force on Policing since the late 1960s, and empirical exploration of whether police morale has taken such a blow that officers are policing less vigorously (Devi \& Fryer, 2020; Mac Donald, 2017; Marier \& Fridell, 2020; Pyrooz et al., 2016; Rosenfeld \& Wallman, 2019; Wolfe \& Nix, 2016). For example, researchers have uncovered evidence of "de-policing" in Baltimore (Morgan \& Pally, 2016; Morgan et al., 2020), Chicago (Arthur \& Asher, 2016), and the state of Missouri (Shjarback et al., 2017) following the death of Freddie Gray, the release of the Laquan McDonald video, and the death of Michael Brown, respectively. ${ }^{2}$ In a national survey of nearly 8,000 police officers conducted in $2016,72 \%$ of responding officers said they were "less willing to stop and question people who seem suspicious" (Pew Research Center, 2017). Line-level and command-level officers also express frustration with how the media portrays law enforcement, and concern about an increased willingness among citizens to challenge police authority (Nix \& Pickett, 2017; Nix et al., 2018).

Research has found that victim characteristics influence news coverage of violence (Bjornstrom et al., 2010; Lin \& Phillips, 2014), because media outlets focus on stories that are attention grabbing, emotionally charged, and consonant with broader themes (Surette, 2011). Given the intense public concern with police killings of Black citizens and the emergence of the Black Lives Matter movement, it seems likely that OIS involving Black suspects will garner greater scrutiny form the media. In OIS involving Black citizens, then,

\footnotetext{
${ }^{2}$ See also "Weekly Crime Reports" at https://www.atlantapd.org/i-want-to/crime-data-downloads. In the first 12 weeks of 2020, Atlanta police officers averaged more than 3,300 traffic stops per week. Even while residents were ordered to stay at home and businesses were closed due to COVID-19, officers never made fewer than 1,000 stops in a week. Yet, from 6/14/2020 to 6/20/2020 - the week immediately following the shooting of Rayshard Brooks - they made just 50. Arrests similarly plunged following the Brooks shooting.
} 
the public-relations challenge for police executives is to dispel notions of obscuration, evidence suppression, or cover up. Theoretically, then, OIS involving Black citizens should increase executives' concerns with demonstrating transparency. Considering this, we hypothesize that when controversial OIS caught on BWC involve Black citizens, police executives will (H2) expect media coverage of the incident to be more negative. Furthermore, (H3) the involvement of a Black citizen in an OIS incident captured on BWC will likely affect the importance executives place on communicating with the public.

Although police shootings of unarmed individuals sometimes are legally justified, they may nevertheless engender frustration and outrage from members of the public, who may not use the same legal standards to judge them (Alpert \& Smith, 1994; Klinger \& Brunson, 2009; Shane \& Swenson, 2018; Selby et al., 2016). Indeed, the public appears to use a simple weapon heuristic to judge OIS, whereby OIS involving unarmed citizens are unjustified. Officers are keen to this reality, and believe the public does not understand their work-especially the intricacies of deadly force incidents (Bartels \& Silverman, 2005; Pew Research Center, 2017).

In this media environment, the public-relations challenge police executives face is that legal use-offorce standards, which focus on officers' threat perceptions, are difficult to explain to the public and are unlikely to be persuasive, because of their complexity and ambiguity. In addition to community expectations, police use of force is regulated by a complex intersection of Constitutional standards, state laws, and agency policies (Stoughton et al., 2020). Further complicating matters, encounters involving police use of force are dramatized by the media and the frequency with which they occur is exaggerated (Marenin, 2016). Thus, for an OIS involving an unarmed citizen, any publicity may equate to bad publicity - at least in the eyes of police executives. For these reasons, we hypothesize that executives will (H4) expect media coverage of an OIS involving an unarmed citizen to be more negative, but (H5) be less supportive of communicating with the public in the aftermath.

\section{The Current Study}

The purpose of this study was twofold. First, we assessed how supportive a nationally representative sample of municipal police executives $(\mathrm{N}=476)$ were of a law that would require them to release BWC footage upon request as public information. Then, to test our hypotheses regarding how executives would perceive and react to a critical incident captured on BWC, we presented the sample with an experimental 
vignette about one of their officers responding to a home invasion call and fatally shooting the suspect. ${ }^{3}$ Policing scholars increasingly are using experimental vignettes to study decision-making (Darwinkel et al., 2013; Hine \& Murphy, 2019; Nix, Pickett, \& Mitchell, 2019; Phillips, 2009; Phillips, 2020), and for good reason. For example, McLean et al. (2020) recently used experimental vignettes involving a suspicious person call to assess the impact of a social interaction training program in two agencies. Although vignettes are cross-sectional and treat effects as one-shot phenomena (Gaines et al., 2007), research shows that decision-making in hypothetical vignettes parallels that in real world situations (Hainmueller et al., 2015; Pogarsky, 2004), and is less susceptible to social desirability bias than direct questioning (Auspurg \& Hinz, 2014). We thus randomized the suspect's race (White or Black) as well as whether he was armed (handgun or cellphone), resulting in a 2x2 full factorial design. Respondents were then asked (1) how they believed media coverage would portray the incident, as well as how important or unimportant it would be to (2) state publicly that the shooting was justified or (3) communicate with the public about the incident in additional ways (e.g., releasing information about the incident, making formal media statements). Before presenting our findings, we briefly review our methodology in the following section.

\section{Method}

Data

Data for this study come from a survey administered to a national probability sample of police executives in early 2018. We obtained the mailing address for 12,039 municipal police departments from the National Directory of Law Enforcement Administrators. Using a sampling strategy similar to that used by the Bureau of Justice Statistics for its Law Enforcement Management and Administrative Statistics (LEMAS) survey, we placed each agency into one of four strata based on the number of sworn officers they employed (i.e., 0 to 24,25 to 49,50 to 99 , and 100 or more). ${ }^{4}$ A random sample of 624 agencies was drawn from each stratum which resulted in a stratified random sample of 2,496 departments.

We used a modified Dillman et al. (2009) method to elicit participation in the study. In February 2018,

\footnotetext{
${ }^{3}$ We described a home invasion in the vignette after consulting with police officers during pilot testing. The officers noted that a home invasion in progress would likely involve dispatch relaying information from the 911 caller, and that officers would approach it with a sense of urgency due to the rather uncommon nature of the call.

${ }^{4}$ Generally speaking, small agencies serve less populous jurisdictions than large agencies. The " 100 or more officers" cutoff is common in police surveys (O'Shea \& Nicholls, 2003). We use it for the largest stratum because of concerns about statistical power. Roughly 40 agencies report having 1,000 or more officers, and only another $\sim 150$ agencies have more than 250 officers (Hyland \& Davis, 2019). This means we would have needed to survey every agency with $250+$ officers and achieved a $60 \%$ or better response rate in order to have sufficient power to detect medium-sized effects.
} 
we pre-notified each agency in our sample with a postcard addressed to the chief executive. The postcard informed them of the survey they would soon receive in the mail, but also included a link to an online version if they preferred to take the survey at that time. We requested that the chief executive complete the survey, or some other high-ranking, command-level officer if the chief was unavailable. One week later, we sent a survey packet to each chief executive in our sample (containing a cover letter, questionnaire, and self-addressed, postage-paid return envelope). Respondents were again given the opportunity to complete the survey online if they preferred. Finally, two weeks later we mailed another survey and reminder letter to agencies that had not yet responded. We received 675 surveys (369 by mail and 306 online), resulting in a $27 \%$ response rate, which falls within the normal range for mail and online police surveys (Nix, Pickett, Baek, et al., 2019). ${ }^{5}$ While the response rate is lower than we hoped, survey methodologists caution against using "minimum acceptable" response rate benchmarks (Groves, 2006; Peytchev, 2013). Further, research demonstrates that survey response rate and non-response bias are only weakly correlated (Peytchev, 2013; Pickett, Cullen, et al., 2018).

\section{Global Outcome Variable: Support for Releasing BWC Footage}

Our first outcome measured executives' global attitudes toward releasing BWC footage (Nix et al., 2020). Specifically, we asked executives to indicate the extent they would "support or oppose a law that would require agencies to release BWC footage upon request as public information” (1=strongly support to $5=$ strongly oppose). Responses were reverse coded so that higher scores indicated greater support.

\section{Independent Variables}

During the survey, each executive randomly received one version of the following factorial vignette:

While on patrol, officers from your agency are dispatched to a home invasion in progress in a residential area. The caller describes the suspect as a [Manipulation A] male. One of your officers arrives on-scene and makes contact with a [Manipulation A] male who fits this description in front of the house. The suspect has his hands in his pockets and does not comply with your officer's commands to show his hands. The suspect then quickly removes his hands

\footnotetext{
${ }^{5}$ We removed two ineligible respondents (who did not work for a municipal agency) and eight respondents who failed to provide enough information to determine the stratum from which they were sampled. For the purposes of our analyses, we restricted the sample to Chiefs (including Interim and Acting Chiefs), which reduced the sample size to $\mathrm{N}=476$.
} 
from his pocket holding an object. Your officer fires at the suspect, killing him on the scene.

Afterward, the officer finds that the object was a [Manipulation B]. The officer's BWC captures

full audio and video of the incident. ${ }^{6}$

Manipulation A was the suspect's race (White or Black) and Manipulation B was whether he was armed (handgun) or unarmed (cellphone). We randomized the factor levels for both, by using random numbers to assign vignettes to agency addresses within each stratum before mailing the questionnaires. These factors serve as independent variables predicting the situational outcomes discussed below. ${ }^{7}$

\section{Experimental Outcome Variables}

Anticipated media coverage. After reading the vignette, executives were asked whether media coverage of the shooting would be: (1) positive or negative, (2) fair or unfair, (3) truthful or untruthful, and (4) reliable or unreliable. For each question, executives were asked to answer on a five-point item-specific response scale (e.g., $1=$ very positive to $5=$ very negative). Factor analysis indicated the four items loaded onto a single factor (eigenvalue $=2.84$, loadings $>.77$ ), so we averaged responses to the items to generate a mean index $(\alpha=.91)$.

State justified. We next asked executives to consider the vignette and indicate how important they felt it would be (regardless of law or policy) for the agency to state publicly that the shooting was justified (1 $=$ very unimportant to $5=$ very important).

Additional communication. Our third situational outcome measured the importance executives placed on additional communication with the public in the aftermath of the OIS. Specifically, we asked respondents to indicate how important it would be (regardless of law or policy) for the agency to: (1) release the video to the public within 48 hours, (2) release demographic information about the involved officer, (3) use social media to keep the community updated on the shooting as details unfold, (4) make a statement to the

\footnotetext{
${ }^{6}$ Surprisingly, national data on officer-involved shootings, disaggregated by the agencies involved and/or their respective populations, are hard to come by. Nix et al. (2017) reported that $68 \%$ of fatal shootings in 2015 involved departments with fewer than 1,000 full-time officers (p. 323). Analyzing seven months of shootings reported by The Washington Post, Sherman (2018) found that the majority of fatal police shootings - 51\% - occurred in communities with fewer than 50,000 residents, and $70 \%$ occurred outside of major cities. Similarly, according to Mapping Police Violence, 74\% of police-involved fatalities from 2013 to 2019 occurred outside of the 100 largest U.S. cities (see https://mappingpoliceviolence.org/cities). Finally, Edwards et al. (2018) showed that two-thirds of all police killings happen in suburbs, smaller cities, and rural counties.

${ }^{7}$ Response rate did not vary as a function of these manipulations. The response rates for each treatment condition were as follows: White suspect $27.8 \%$, Black suspect $26.12 \%$; armed suspect $26.84 \%$, unarmed suspect $27.08 \%$. Our experiment achieved good balance-respondent characteristics (gender, race/ethnicity, and education) and agency use of body-worn cameras were very similar across experimental groups. Additionally, the sample mirrors the population of local police chiefs in terms of race/ethnicity (91\% White) and gender (96\% male); see Hyland and Davis (2019)). See Tables A1-A3 in the supplemental appendices.
} 
media regarding the shooting within 24 hours, and (5) send someone to meet with the suspect's family to discuss the incident. The five items loaded onto a single factor (eigenvalue $=1.31$, loadings $>.43$ ), and as such, we averaged responses to create a mean index $(\alpha=.64){ }^{8}$

\section{Analytic Strategy}

Two of our outcomes were continuous mean indices and one was ordinal. Research suggests linear probability models are appropriate in experiments for categorical outcomes (Gomila, 2019; Huang, 2019). To test our hypotheses, we estimated linear regression models and used randomization inference to conduct hypothesis tests (Gerber \& Green, 2012; Keele et al., 2012). ${ }^{9}$ Randomization inference is an exact test of the sharp null hypothesis of no effect, which is based on random assignment within the finite sample, rather than on large sample theory. It requires no parametric distributional assumptions, is valid with non-normally distributed outcomes, in the presence of outliers, and regardless of sample size (Gerber \& Green, 2012). Because we tested our hypotheses across each of four strata, the false positive rate is inflated. As such, we use a Bonferroni-corrected alpha threshold of $.0125 .^{10}$

\section{Results}

Figure 1 breaks down executive support/opposition for legislation that would require agencies to release BWC footage upon request as public information. Across each stratum, approximately half of the executives opposed or strongly opposed such legislation, whereas only 24 to $30 \%$ indicated support or strong support. The remaining 22 to $23 \%$ in each stratum were neutral, expressing neither support nor opposition. The distribution of responses across the four strata were statistically indistinguishable (Pearson's $\chi^{2}$ $=10.991, \mathrm{p}=.53)$, suggesting that agency size is not associated with support or opposition for this type of legislation. Therefore, our first hypothesis was not supported.

\section{[FIGURE 1 HERE]}

\footnotetext{
${ }^{8}$ We also performed each factor analysis separately for each stratum. In each stratum, the items used to create the anticipated media coverage and additional communication scales loaded onto a single factor and exhibited adequate internal consistency. We also re-estimated our regression models using weighted factor scores instead of mean scales for these two outcomes. Results were substantively similar (see Tables B1 and C1 in the supplemental appendices).

${ }^{9}$ We estimated supplemental models for the ordinal outcome using ordered logistic regression. The results were substantively similar (see Table D1 in the supplemental appendices).

${ }^{10}$ When testing interactions in the full sample, where the four strata are combined, we do not use this Bonferroni corrected alpha.
} 
Turning attention to the experimental portion of the analysis, Table 1 displays the effects of our two randomized factors (Black/White and armed/unarmed suspect) on three outcomes (anticipated media, state justified, additional communication) within each of the four strata. We will discuss each factor in turn. In the smallest agencies (0-24 sworn), the suspect's race did not significantly influence chief executives' concerns about media hostility, willingness to state publicly that the shooting was justified, or willingness to engage in additional dialogue about the incident with the community. The same was true of executives in the third stratum (50 to 99 sworn). However, suspect race did have a significant effect on the decisionmaking process of chief executives in agencies with 25 to 49 officers and those in agencies with 100 or more officers. On one hand, chiefs serving agencies with 25 to 49 officers anticipated greater media hostility if the suspect was Black $(b=.326, p=.006)$. On the other hand, chiefs serving the largest agencies indicated that media coverage would be less hostile if the suspect involved was Black $(b=-.223, p<.000)$. Here, we found partial support for our second and third hypothesis.

Regarding our second randomized factor - the armed/unarmed status of the suspect - we found it did not have a significant effect on any of the outcomes we measured in the smallest and largest agencies. However, in the two middle strata, results indicate it influenced executives' concerns about media hostility and willingness to state publicly that the shooting was justified. Taken together, these findings indicate partial support for our fourth and fifth hypotheses. Among agencies with 25 to 49 officers, executives expected greater media hostility if the suspect pulled a cellphone, as opposed to a firearm, from his pocket ( $b=.314, p=.008)$. Moreover, and perhaps unsurprisingly, they expressed significantly less willingness to state publicly that the shooting was justified if the suspect had a cellphone $(b=-.836, p<.000)$. A similar pattern of findings emerged among chiefs serving agencies with 50 to 99 officers. They expected more hostile media coverage $(b=.427, p=.002)$, and were less willing to state publicly that the shooting was justified $(b=-.692, p=.001)$, if the suspect had a cellphone.

\section{[TABLE 1 HERE]}

A key finding, then, was that the effects of the randomizations on some of our outcomes - notably anticipated media hostility and state justified - varied by agency size. Inspection of the coefficients for the variable unarmed suspect across the strata suggests its effect on anticipated media hostility may increase linearly with agency size. Conversely, its effect on willingness to state publicly that the shooting was justified appears non-linear, with the most substantial impact on executives serving agencies in the two 
middle strata. To test for these possibilities, we combined the four strata into a single, full sample and created an interaction terms, unarmed*agency size, where agency size was an ordinal variable ranging from 1 ( 0 to 24 officers) to 4 (100 or more officers). We then estimated ordinary least squares regression models for two outcomes: anticipated media hostility and state justified. Using the margins command in Stata (version 15.1), we plotted adjusted predictions for the effect of unarmed suspect on each outcome, at each of the four strata (i.e., the interaction between unarmed suspect and agency size in the full sample). The results are depicted in Figures 2 and $3 .^{11}$

[FIGURE 2 HERE]

In the first model predicting anticipated media hostility, the coefficient for the interaction term unarmed $^{*}$ agency size was positive and statistically significant $(b=.265, \mathrm{p}<.000)$. As shown in Figure 2 , the difference in anticipated media coverage if the shooting involved an armed suspect relative to an unarmed suspect grows larger with agency size. In the second model predicting state justified, the coefficient for the interaction term unarmed*agency size was negative and statistically significant only at the second and third categories of agency size $(b=-.809, p=.001$ and $b=-.669, p=.011$, respectively). In Figure 3 , the effect of unarmed suspect on willingness to state publicly that the shooting was justified is most pronounced in the second stratum (25-49 officers), less pronounced in the third stratum (50-99 officers), and statistically nonsignificant in the largest stratum $(b=-.362, p=.204)$. With these findings in mind we next discuss the implications of our work in light of its limitations, and provide directions for future research.

\section{[FIGURE 3 HERE]}

\section{Discussion}

The push for police departments to adopt BWCs has resulted in a dramatic increase in the number of agencies utilizing them, with approximately half of all departments equipping their officers with BWCs as of 2016 (Hyland, 2018). Unlike previous technological innovations that have diffused throughout policing before empirical evidence could catch up, the proliferation of BWCs has been accompanied by a simultaneous explosion of research on their effects. Since 2012, over 70 BWC evaluation studies - many in the form of randomized controlled trials - have been published (Lum et al., 2019). The evidence is decidedly mixed,

\footnotetext{
${ }^{11}$ Model fit statistics (adjusted $\mathrm{R}^{2}$, AIC) support the decision in the interaction models to treat agency size as ordinal for anticipated media and as categorical for state justified.
} 
but collectively suggests that in some contexts BWCs can be beneficial to both officers and citizens (Malm, 2019). However, the current study is the first, to our knowledge, to explore law enforcement executives' perceptions about transparency issues surrounding BWC-recorded OIS. Given that many of the demands for BWCs stem from the expectation that BWCs will increase transparency (President's Task Force on 21st Century Policing, 2015; White \& Malm, 2020), it is imperative to understand the attitudes and perceptions of the individuals who control the footage and make decisions about its release. Additionally, we explored how factors like suspect characteristics and media coverage - those outside of the executives' control might influence their decision making in the aftermath of an OIS captured on BWC. The results of our various hypothesis tests are summarized in Table 2.

[TABLE 2 HERE]

The results indicated that less than one-third of executives in our sample supported legislation that would mandate the release of BWC footage upon request as public information. Contrasting our first hypothesis, we found similar levels of support among executives at both small and large agencies. The finding that only a small minority of executives at all agency types support mandatory release of BWC footage indicates that they are not fully on board with transparency. Instead, executives appear to be on board with transparency only when they can decide on a case-by-case basis exactly how transparent they want to be. Such case-by-case decision making is the very problem that transparency reforms are designed to address. A key takeaway, then, is that if policing is to become more transparent, and if BWC footage is to increase accountability through open access, then the impetus for moving beyond case-by-case decisionmaking will have to come from outside of policing, most likely from legislators.

According to National Conference of State Legislatures (2018), twenty-seven states do not currently have laws pertaining to how BWC footage must be addressed under open record laws. Even in the states that do, there are usually built-in exemptions that allow agencies to deny FOIA requests (e.g., if the footage pertains to an ongoing investigation). Thus, public release of BWC footage is often left to the discretion of the Chief of Police or Sheriff in many jurisdictions. However, in response to calls for police reform (Bazelon, 2020; Chang, 2020) following the police killing of George Floyd in Minneapolis, Minnesota, some cities and states have introduced legislation that mandate the release of BWC footage within a prespecified number of days (New York City Hall, 2020; Colorado State Senate SB 20-217, n.d.). As a result, the decision to release footage no longer rests with department executives in these areas. To the extent that a uniform response 
by police departments following a critical incident is desirable, and in light of our findings that executives' want the option to withhold BWC footage and that their willingness to exhibit transparency varies across OISs types, such legislation is exactly what is needed.

In the meantime, our results suggest that executives believe there are at least some situations in which withholding BWC footage from the public is acceptable and/or necessary. Otherwise, they would have no issue with laws that mandate releasing footage. One possibility is that they are concerned with how certain types of BWC footage will make their agencies look. Another more benign explanation is that they may be concerned about the costs associated with dedicating human resources to review and redact BWC footage when public records requests are made (White \& Malm, 2020). Currently, many jurisdictions are permitted to charge citizens a fee for releasing BWC footage as part of a public information request in order to offset cost. For example, in Washington, state law RCS 42.56.240(14) allows local agencies to charge citizens for "reasonable costs of redacting, altering, distorting, pixelating, suppressing, or otherwise obscuring any portion of the... recording prior to disclosure." Similarly, the Las Vegas Metropolitan Police Department charges $\$ 48$ per hour for the processing of a BWC recording to redact confidential information. ${ }^{12}$ Simply put, some chiefs may be fearful that their agencies would bear the brunt of the financial burden associated with laws that mandate the release of BWC footage (Hyland, 2018). Moving forward, qualitative research is needed to help understand why chiefs do or do not support such legislation. Future research could also explore executives' views about whether it is necessary to withhold certain types of footage from the public, and if so, what they are.

Turning to the experimental component of our study, we found that the effects of suspect race and his armed/unarmed status on executives' decision-making varied with agency size. Most notably, as agency size increased, executives became more likely to believe that OISs involving unarmed suspects would result in negative publicity. In this respect, we found partial support for our fourth hypothesis that executives would expect media coverage of an OIS involving an unarmed citizen to be more negative. It is possible that smaller departments enjoy a different type of relationship with their local media that insulates them from the type of scrutiny that is placed on larger agencies by national media outlets (Chermak \& Weiss, 2005; Matusiak, 2019). In addition, an OIS is likely not as novel within large departments. Whereas a fatal OIS represents a relatively infrequent occurrence for many small departments, larger departments might

\footnotetext{
${ }^{12}$ See https://www.bwcscorecard.org/static/policies/2016-08-17\%20Las\%20Vegas\%20-\%20BWC\%20Video\%20Request\% 20Policy.pdf.
} 
not expect a shooting to alter media coverage since they occur more frequently. In larger cities, those covered by major new organizations, the media may be more conditioned to shootings and more likely to lend authority and legitimacy to the police department involved in the shooting (Hirschfield \& Simon, 2010).

Counter to our expectations, executives from the largest agencies believed media coverage would be less hostile if the officer fatally shot a Black suspect. Speculatively, we can think of a few possible explanations. One is that larger agencies are more likely to have non-White officers, and our experiment did not specify the officer's race. So, the executives in larger agencies may have been less likely to assume that the OIS was interracial. Another possible explanation is that executives in larger agencies may have more experience with Black-suspect OISs, given that bigger cities tend to have larger Black populations than other locales. Alternatively, it may be that in larger cities, executives assume that a Black-suspect OIS will be less newsworthy, especially if the suspect is armed, because violence against Black people is more common generally-it may just be seen as "a fact of life," in other words. Unfortunately, our sample size was insufficient to test a three-way-interaction between the experimental factors and agency size. Future research should explore this possibility. Finally, it may be that the surprising experimental finding was simply due to chance. This explanation is the most likely in our view.

Another notable finding was the effect of the suspect being unarmed on decision-making among executives at mid-sized agencies. When the suspect was unarmed, executives in mid-sized agencies were significantly less likely to indicate they would state publicly that the shooting was justified. This could mean that agency size affects executives' baseline views about the importance of communicating with the public - or their baseline likelihood of perceiving shootings as justified - and that these baseline effects, in turn, make executives in mid-sized agencies most sensitive to situational circumstances like the presence of an unarmed suspect. Indeed, all else equal, the executives at the smallest agencies in our sample were the most likely to believe it was important to state publicly that the hypothetical shooting was justified. One protentional explanation is that OIS involving smaller agencies are less likely to influence chiefs' willingness to be transparent because of OIS do not occur as frequently. In such agencies, therefore, situational factors may simply have less room to influence executives' decisions about public communication after OIS.

Our experimental findings suggest that agency size may condition the effects of situational variables on executive decision-making because it influences experiences with OIS and media coverage. With that 
in mind, it seems plausible that executives at larger agencies are more experienced in dealing with OIS because their officers are more frequently involved in OIS (J. Jennings \& Rubado, 2017; Smith, 2004). This familiarity also provides a better understanding of the type of media coverage that typically follows OIS, civilian injuries or deaths while in police custody, or other events that could potentially strain policecommunity relations. Future research should continue to explore situational differences in OIS and media experiences across agencies of different sizes and locations, and how they affect executives' and officers' attitudes.

Our study was not without limitations. First, only 27 percent of our sample responded to the survey. Although this response rate falls within the normal range for mail survey research of police samples (Nix, Pickett, Baek, et al., 2019), it raises the possibility that nonresponse bias may undermine the external validity of our findings. Second, Models $10-12$ of Table 1 (which correspond to agencies in the 100+ sworn group) were slightly underpowered to detect medium-sized effects due to their smaller Ns. Third, we presented the executives with a hypothetical vignette. This is a widely used method for analyzing judgment and decision-making (Auspurg \& Hinz, 2014; Pickett, Roche, et al., 2018; Reisig et al., 2018), and our use of randomization enhances the internal validity of our design - but it is nevertheless artificial. We also did not manipulate other relevant details, such as the presence of victims or witnesses (Garner et al., 2002), dispatch priming (Taylor, 2019), or the suspect's demeanor (Nix, Pickett, \& Mitchell, 2019) - each of which might factor into an executive's assessment of the OIS and subsequent decision making. Future research should explore whether these factors play a role in executives' decision making as it relates to release of BWC footage. Finally, our largest stratum (100+ officers) was more heterogenous in terms of agency size than the other three. With that heterogeneity comes greater variation in other potentially important factors, such as urbanicity or social context. As a result, the moderating effects of agency size depicted in Figures 2 and 3 may reflect the effect of some unobserved factor that is correlated with agency size - an observational variable - and that also moderates the effect of the experimental manipulations. Additional analyses reported in Tables E1-E2 of the Supplemental Appendices suggest that variation in each agency's community population and violent crime rate do not alter our findings. Nevertheless, future research might consider other factors such as agencies' operating budgets or officer-involved shooting rates. Future research should also consider a different sampling strategy that would permit distinguishing agencies with, for example, 1,000+ officers from those with 100 to 500.

BWCs are now part of policing and we can expect that they are here to stay. Research demonstrates 
that both police and citizens support the use of BWCs (Gaub et al., 2018; McClure et al., 2017; Todak et al., 2018; White \& Malm, 2020). However, supporting their use is different than supporting the release of BWC footage. As such, more empirical attention is needed to understand views about release of footage, and the response to that footage (Lum et al., 2019). Our study shows that only a minority of police executives in the United States support a law mandating video release. Our findings also reveal that agency size influences police executives' decisions about BWC and OIS, moderating the effects of situational factors, such as the presence of an unarmed suspect. These findings give rise to two new research questions: 1) what specific concerns motivate executives' opposition to releasing BWC footage? and 2) what agency- and city-level factors give rise to the heterogeneous, situational effects observed herein? We hope that future studies will address these questions and continue to hone the measures introduced in this paper, as we found evidence that the measurement quality of our additional communication item varied across stratum (see Table B1 of supplemental appendices). Specifically, researchers should attempt to replicate our methods and build on them by varying important contextual details surrounding the incident. More generally, we call on scholars to devote greater theoretical and empirical attention to the various public-communication issues surrounding BWC and OIS. 


\section{References}

Alpert, G., MacDonald, J., \& Dunham, R. (2005). Police suspicion and discretionary decision making during citizen stops. Criminology, 43(2), 407-434.

Alpert, G., \& Smith, W. (1994). How reasonable is the reasonable man? Police and excessive force. fournal of Criminal Law and Criminology, 85(2), 481-501.

Ariel, B., Farrar, W., \& Sutherland, A. (2015). The effect of police body-worn cameras on use of force and citizens' complaints against the police: A randomized controlled trial. Fournal of Quantitative Criminology, 31(3), 509-535.

Ariel, B., Sutherland, A., Henstock, D., Young, J., Drover, P., Sykes, J., Megicks, S., \& Henderson, R. (2017). Contagious Accountability: A global multisite randomized controlled trial on the effect of police body-worn cameras on citizens' complaints against the police. Criminal fustice and Behavior, 44(2), 293-316.

Arthur, R., \& Asher, J. (2016). Gun Violence Spiked-And Arrests Declined-In Chicago Right After the Laquan McDonald Video Release. FiveThirtyEight. https :/ fivethirtyeight. com/features / gun violence - spiked - and - arrests - declined - in - chicago - right - after - the - laquan - mcdonald - video release/

Auspurg, K., \& Hinz, T. (2014). Factorial Survey Experiments. SAGE Publications.

Bartels, E., \& Silverman, E. (2005). An exploratory study of the New York City Civilian Complaint Review Board mediation program. Policing: An International fournal of Police Strategies \& Management, 28(4), 619-630.

Bazelon, E. (2020). Police reform is necessary. But how do we do it? https://www.nytimes.com/interactive/ 2020/06/13/magazine/police-reform.html.

Bjornstrom, E., Kaufman, R., Peterson, R., \& Slater, M. (2010). Race and ethnic representation of lawbreakers and victims in crime news: A national study of television coverage. Social Problems, 57(2), 269-293.

Braga, A., Sousa, W., Coldren, J., \& Rodriguez, D. (2018). The effects of body-worn cameras on police activity and police-citizen encounters: A randomized controlled trial criminology. fournal of Criminal Law and Criminology, 108(3), 511-538.

Chang, A. (2020). California Attorney General calls for police reform in the state. https://www.npr.org/2020/ 06/15/877618069/california-attorney-general-calls-for-police-reform-in-the-state.

Chermak, S., \& Weiss, A. (2005). Maintaining legitimacy using external communication strategies: An analysis of police-media relations. fournal of Criminal fustice, 33(5), 501-512.

Colorado State Senate SB 20-217. (n.d.).

Darwinkel, E., Powell, M., \& Tidmarsh, P. (2013). Improving police officers' perception of sexual offending through intensive training. Criminal fustice and Behavior, 40, 895-908.

Devi, T., \& Fryer, J., Roland G. (2020). Policing the police: The impact of "pattern-or-practice" investigations on crime (Working Paper No. 27324). National Bureau of Economic Research. https://doi.org/10. 3386/w27324

Dillman, D., Phelps, G., Tortora, R., Swift, K., Kohrell, J., Berck, J., \& Messer, B. (2009). Response rate and measurement differences in mixed-mode surveys using mail, telephone, interactive voice response (IVR) and the Internet. Social Science Research, 38(1), 1-18.

Edwards, F., Esposito, M., \& Lee, H. (2018). Risk of police-involved death by race/ethnicity and place, United States, 2012-2018. American fournal of Public Health, 108(9), 1241-1248.

Edwards, F., Lee, H., \& Esposito, M. (2019). Risk of being killed by police use of force in the United States by age, race-ethnicity, and sex. Proceedings of the National Academy of Sciences, 116(34), 16793-16798.

Fryer Jr, R. G. (2016). An empirical analysis of racial differences in police use of force [Issue: w22399)]. National Bureau of Economic Research. 
Gaines, B., Kuklinski, J., \& Quirk, P. (2007). The logic of the survey experiment reexamined. Political Analysis, 15(1), 1-20.

Garner, J., Maxwell, C., \& Heraux, C. (2002). Characteristics associated with the prevalence and severity of force used by the police. fustice Quarterly, 19(4), 705-746.

Gaub, J., Todak, N., \& White, M. (2018). One size doesn't fit all: The deployment of police body-worn cameras to specialty units. International Criminal fustice Review. Advance online publication. https: //doi.org/10.1177/1057567718789237.

Gerber, A., \& Green, D. (2012). Field Experiments: Design, Analysis, and Interpretation (1st). W. W. Norton \& Company.

Goetschel, M., \& Peha, J. (2017). Police perceptions of body-worn cameras. American fournal of Criminal fustice, 42(4), 698-726.

Goff, P., Lloyd, T., Geller, A., Raphael, S., \& Glaser, J. (2016). The science of justice: Race, arrests, and police use of force. Center for Policing Equity.

Goldstein, J. (1960). Police discretion not to invoke the criminal process: Low-visibility decisions in the administration of justice. The Yale Law fournal, 69(4), 543-594.

Gomila, R. (2019). Logistic or linear? Estimating causal effects of treatments on binary outcomes using regression analysis. PsyArXiv. https://doi.org/10.31234/osf.io/4gmbv.

Groves, R. (2006). Nonresponse rates and nonresponse bias in household surveys. Public Opinion Quarterly, $70(5), 646-675$.

Hainmueller, J., Hangartner, D., \& Yamamoto, T. (2015). Validating vignette and conjoint survey experiments against real-world behavior. Proceedings of the National Academy of Sciences, 112(8), 23952400 .

Hine, B., \& Murphy, A. (2019). The influence of 'High' vs. 'Low' rape myth acceptance on police officers' judgements of victim and perpetrator responsibility, and rape authenticity. fournal of Criminal Fustice, 60, 100-107.

Hirschfield, P., \& Simon, D. (2010). Legitimating police violence: Newspaper narratives of deadly force. Theoretical Criminology, 14(2), 155-182.

Huang, F. (2019). Alternatives to logistic regression models in experimental studies. The fournal of Experimental Education. Advance online publication. https://doi.org/10.1080/00220973.2019.1699769.

Husain, N. (2019). Laquan McDonald timeline: The shooting, the video, the verdict and the sentencing. Chicago Tribune. https://www.chicagotribune.com/news/laquan-mcdonald/ct-graphics-laquanmcdonald-officers-fired-timeline-htmlstory.html.

Hyland, S. (2018). Body-worn cameras in law enforcement agencies, 2016 (NCJ 251775). Bureau of Justice Statistics. https://www.bjs.gov/content/pub/pdf/bwclea16.pdf

Hyland, S., \& Davis, E. (2019). Local police departments, 2016: Personnel (NCJ 252835). Bureau of Justice Statistics. https://www.bjs.gov/content/pub/pdf/lpd16p.pdf

Jacobs, D., \& O'Brien, R. (1998). The determinants of deadly force: A structural analysis of police violence. American fournal of Sociology, 103(4), 837-862.

James, L., James, S., \& Vila, B. (2016). The reverse racism effect: Are cops more hesitant to shoot black than white suspects? Criminology \& Public Policy, 15(2), 457-479.

Jennings, J., \& Rubado, M. (2017). Preventing the use of deadly force: The relationship between police agency policies and rates of officer-involved gun deaths. Public Administration Review, 77(2), 217226.

Jennings, W., Fridell, L., \& Lynch, M. (2014). Cops and cameras: Officer perceptions of the use of body-worn cameras in law enforcement. Fournal of Criminal fustice, 42(6), 549-556.

Katz, C., Choate, D., Ready, J., \& Nuňo, L. (2014). Evaluating the Impact of Officer Worn Body Cameras in the Phoenix Police Department. Center for Violence Prevention \& Community Safety. 
Keele, L., McConnaughy, C., \& White, I. (2012). Strengthening the experimenter's toolbox: Statistical estimation of internal validity. American fournal of Political Science, 56(2), 484-499.

Klinger, D., Rosenfeld, R., Isom, D., \& Deckard, M. (2016). Race, crime, and the micro-ecology of deadly force. Criminology \& Public Policy, 15(1), 193-222.

Klinger, D., \& Brunson, R. (2009). Police officers' perceptual distortions during lethal force situations: Informing the reasonableness standard. Criminology \& Public Policy, 8(1), 117-140.

Knox, D., \& Mummolo, J. (2020). Making inferences about racial disparities in police violence. Proceedings of the National Academy of Sciences, 117(3), 1261-1262.

Lin, J., \& Phillips, S. (2014). Media coverage of capital murder: Exceptions sustain the rule. Fustice Quarterly, 31(5), 934-959.

Liska, A., \& Yu, J. (1992). Specifying and testing the threat hypothesis: Police use of deadly force. In A. Liska (Ed.), Social Threat and Social Control (pp. 53-68). State University of New York Press.

Lum, C., Stoltz, M., Koper, C., \& Scherer, J. (2019). Research on body-worn cameras: What we know, what we need to know. Criminology \& Public Policy, 18(1), 93-118.

Mac Donald, H. (2017). The War on Cops: How the New Attack on Law and Order Makes Everyone Less Safe. Encounter Books.

MacDonald, J., Kaminski, R., Alpert, G., \& Tennenbaum, A. (2001). The temporal relationship between police killings of civilians and criminal homicide: A refined version of the danger-perception theory. Crime \& Delinquency, 47(2), 155-172.

Malm, A. (2019). Promise of police body-worn cameras. Criminology \& Public Policy, 18(1), 119-130.

Marenin, O. (2016). Cheapening death: Danger, police street culture, and the use of deadly force. Police Quarterly, 19(4), 461-487.

Marier, C., \& Fridell, L. (2020). Demonstrations, demoralization, and de-policing. Criminology \& Public Policy. Advance online publication. https://doi.org/10.1111/1745-9133.12492

Matusiak, M. (2019). Environmental predictors of municipal police agency goals. Police Quarterly, 22(1), 112-136.

McClure, D., La Vigne, N., Lynch, M., Golian, L., Lawrence, D., \& Malm, A. (2017). How body cameras affect community members' perceptions of police: Results from a randomized controlled trial of one agency's pilot. Urban Institute. https://www.urban.org/sites/default/files/publication/91331/2001307-howbody-cameras-affect-community-members-perceptions-of-police_2.pdf.

McLean, K., Wolfe, S., Rojek, J., Alpert, G., \& Smith, M. (2020). A randomized controlled trial of social interaction police training. Criminology \& Public Policy, 19(3), 805-832.

Morgan, S., Miller, R., Ferguson, G., Sousa, D. W. D., Tuggle, \& Too, H. (2020). An Analysis of Recorded Crime Incidents and Arrests in Baltimore City. https://doi.org/10.31235/osf.io/fcm7t

Morgan, S., \& Pally, J. (2016). Ferguson, Gray, and Davis: An Analysis of Recorded Crime Incidents and Arrests in Baltimore City. https://doi.org/10.31235/osf.io/nshme

Mourtgos, S., \& Adams, I. (2019). Assessing public perceptions of police use-of-force: Legal reasonableness and community standards. Justice Quarterly. Advance online publication. https://doi.org/10.1080/ 07418825.2019.1679864.

National Conference of State Legislatures. (2018). Law enforcement overview. http://www.ncsl.org/research/ civil-and-criminal-justice/lawenforcement.aspx\#3.

New York City Hall. (2020). Mayor de Blasio announces new body camera footage policy. https://www1.nyc. gov/office-of-the-mayor/news/438-20/mayor-de-blasio-new-body-camera-footage-policy.

Nix, J., Campbell, B., Byers, E., \& Alpert, G. (2017). A bird's eye view of civilians killed by police in 2015: Further evidence of implicit bias. Criminology \& Public Policy, 16(1), 309-340.

Nix, J., \& Pickett, J. (2017). Third-person perceptions, hostile media effects, and policing: Developing a theoretical framework for assessing the Ferguson effect. fournal of Criminal fustice, 51, 24-33. 
Nix, J., Pickett, J., Baek, H., \& Alpert, G. (2019). Police research, officer surveys, and response rates. Policing and Society, 29(5), 530-550.

Nix, J., Pickett, J., \& Mitchell, R. (2019). Compliance, noncompliance, and the in-between: Causal effects of civilian demeanor on police officers' cognitions and emotions. Fournal of Experimental Criminology, 15(4), 611-639.

Nix, J., Todak, N., \& Tregle, B. (2020). Understanding body-worn camera diffusion in u.s. policing. Police Quarterly, 23(3), 396-422.

Nix, J., Wolfe, S., \& Campbell, B. (2018). Command-level police officers' perceptions of the "War on Cops" and de-policing. Fustice Quarterly, 35(1), 33-54.

O’Shea, T., \& Nicholls, K. (2003). Police crime analysis: A survey of US police departments with 100 or more sworn personnel. Police Practice and Research, 4(3), 233-250.

Owens, C., \& Finn, W. (2018). Body-worn video through the lens of a cluster randomized controlled trial in London: Implications for future research. Policing: A fournal of Policy and Practice, 12(1), 77-82.

Pelfrey Jr., W., \& Keener, S. (2016). Police body worn cameras: A mixed method approach assessing perceptions of efficacy. Policing: An International fournal of Police Strategies \& Management, 39(3), 491506.

Pew Research Center. (2017). Behind the Badge: Amid protests and calls for reform, how police view their jobs, key issues and recent fatal encounters between blacks and police. https://www.pewsocialtrends.org/ 2017/01/11/behind-the-badge/.

Pew Research Center. (2019). Mobile technology and home broadband, 2019. https://www.pewresearch.org/ internet/2019/06/13/mobile-technology-and-home-broadband-2019/.

Peytchev, A. (2013). Consequences of survey nonresponse. The ANNALS of the American Academy of Political and Social Science, 645(1), 88-111.

Phillips, S. (2009). Using a vignette research design to examine traffic stop decision making of police officers: A research note. Criminal fustice Policy Review, 20, 495-506.

Phillips, S. (2020). The formation of suspicion: A vignette study. International fournal of Police Science \& Management. Advance online publication. https://doi.org/10.1177/1461355720929038.

Pickett, J., Cullen, F., Bushway, S., Chiricos, T., \& Alpert, G. (2018). The response rate test: Nonresponse bias and the future of survey research in criminology and criminal justice. The Criminologist, 43(1), 7-11.

Pickett, J., Roche, S., \& Pogarsky, G. (2018). Toward a bifurcated theory of emotional deterrence: Fear and deterrence. Criminology, 56(1), 27-58.

Pogarsky, G. (2004). Projected offending and contemporaneous rule-violation: Implications for heterotypic continuity. Criminology, 42(1), 111-136.

President's Task Force on 21st Century Policing. (2015). Office of Community Oriented Policing Services.

Pyrooz, D., Decker, S., Wolfe, S., \& Shjarback, J. (2016). Was there a Ferguson Effect on crime rates in large U.S. cities? Journal of Criminal fustice, 46, 1-8.

Reisig, M., Mays, R., \& Telep, C. (2018). The effects of procedural injustice during police-citizen encounters: A factorial vignette study. Journal of Experimental Criminology, 14(1), 49-58.

Rosenfeld, R., \& Wallman, J. (2019). Did de-policing cause the increase in homicide rates? Criminology \& Public Policy, 18(1), 51-75.

Ross, C. (2015). A multi-level Bayesian analysis of racial bias in police shootings at the county-level in the United States, 2011-2014. PloS one, 10(11).

Ross, C., Winterhalder, B., \& McElreath, R. (2018). Resolution of apparent paradoxes in the race-specific frequency of use-of-force by police. Palgrave Communications, 4(1), 1-9.

Schwartz, G., \& Jahn, J. (2020). Mapping fatal police violence across U.S. metropolitan areas: Overall rates and racial/ethnic inequities, 2013-2017. PLOS ONE, 15(6), 0229686. https://doi.org/10.1371/journal. pone. 0229686 
Selby, N., Singleton, B., MS, E., Bruce, C., \& Mulvey, L. (2016). In A. Harley \& Ed) (Eds.), Context: Understanding Police Killings of Unarmed Civilians. CIAI Press.

Shane, J., \& Swenson, Z. (2018). Unarmed and Dangerous: Patterns of Threats by Citizens During Deadly Force Encounters with Police. Routledge.

Sherman, L. (2018). Reducing fatal police shootings as system crashes: Research, theory, and practice. Annual Review of Criminology, 1, 421-449.

Shjarback, J., Pyrooz, D., Wolfe, S., \& Decker, S. (2017). De-policing and crime in the wake of Ferguson: Racialized changes in the quantity and quality of policing among Missouri police departments. fournal of Criminal fustice, 50, 42-52. https://doi.org/10.1016/j.jcrimjus.2017.04.003

Smith, B. (2004). Structural and organizational predictors of homicide by police. Policing: An International fournal of Police Strategies and Management, 27(4), 539-557.

Sorensen, J., Marquart, J., \& Brock, D. (1993). Factors related to killings of felons by police officers: A test of the community violence and conflict hypotheses. Fustice Quarterly, 10(3), 417-440.

Sousa, W., Miethe, T., \& Sakiyama, M. (2018). Inconsistencies in public opinion of body-worn cameras on police: Transparency, trust, and improved police-citizen relationships. Policing: A fournal of Policy and Practice, 12(1), 100-108.

Stoughton, S., Noble, J., \& Alpert, G. (2020). Evaluating police uses of force. NYU Press.

Surette, R. (2011). Media, crime and criminal justice: Images, realities, and politics (4th ed.). Wadsworth.

Taylor, P. (2019). Dispatch Priming and the Police Decision to Use Deadly Force. Police Quarterly. Advance online publication. https://doi.org/10.1177/1098611119896653.

Telep, C., \& Winegar, S. (2016). Police executive receptivity to research: A survey of chiefs and sheriffs in Oregon. Policing: A fournal of Policy and Practice, 10(3), 241-249.

Todak, N., Gaub, J., \& White, M. (2018). The importance of external stakeholders for police body-worn camera diffusion. Policing: An International fournal, 41(4), 448-464.

Turner, F., \& Fox, B. (2019). Public servants or police soldiers? An analysis of opinions on the militarization of policing from police executives, law enforcement, and members of the 114th Congress US House of Representatives. Police Practice and Research, 20(2), 122-138.

Voigt, R., Camp, N., Prabhakaran, V., Hamilton, W., Hetey, R., Griffiths, C., \& Eberhardt, J. (2017). Language from police body camera footage shows racial disparities in officer respect. Proceedings of the National Academy of Sciences, 114(25), 6521-6526.

White, M., \& Fradella, H. (2017). The intersection of law, policy, and police body-worn cameras: An exploration of critical issues badge cams as data and deterrent: Enforcement, the public, and the press in the age of digital video. North Carolina Law Review, 96(5), 1579-1638.

White, M., Gaub, J., \& Todak, N. (2018). Exploring the potential for body-worn cameras to reduce violence in police-citizen encounters. Policing: A Journal of Policy and Practice, 12(1), 66-76.

White, M., \& Malm, A. (2020). Cops, Cameras, and Crisis: The Potential and the Perils of Police Body-Worn Cameras. NYU Press.

Wolfe, S., \& Nix, J. (2016). The alleged "Ferguson Effect" and police willingness to engage in community partnership. Law and Human Behavior, 40(1), 1-10.

Wolfe, S., Nix, J., \& Campbell, B. (2018). Police managers' self-control and support for organizational justice. Law and Human Behavior, 42(1), 71. 
Figure 1. Support for legislation that would require agencies to release BWC footage upon request as public information.

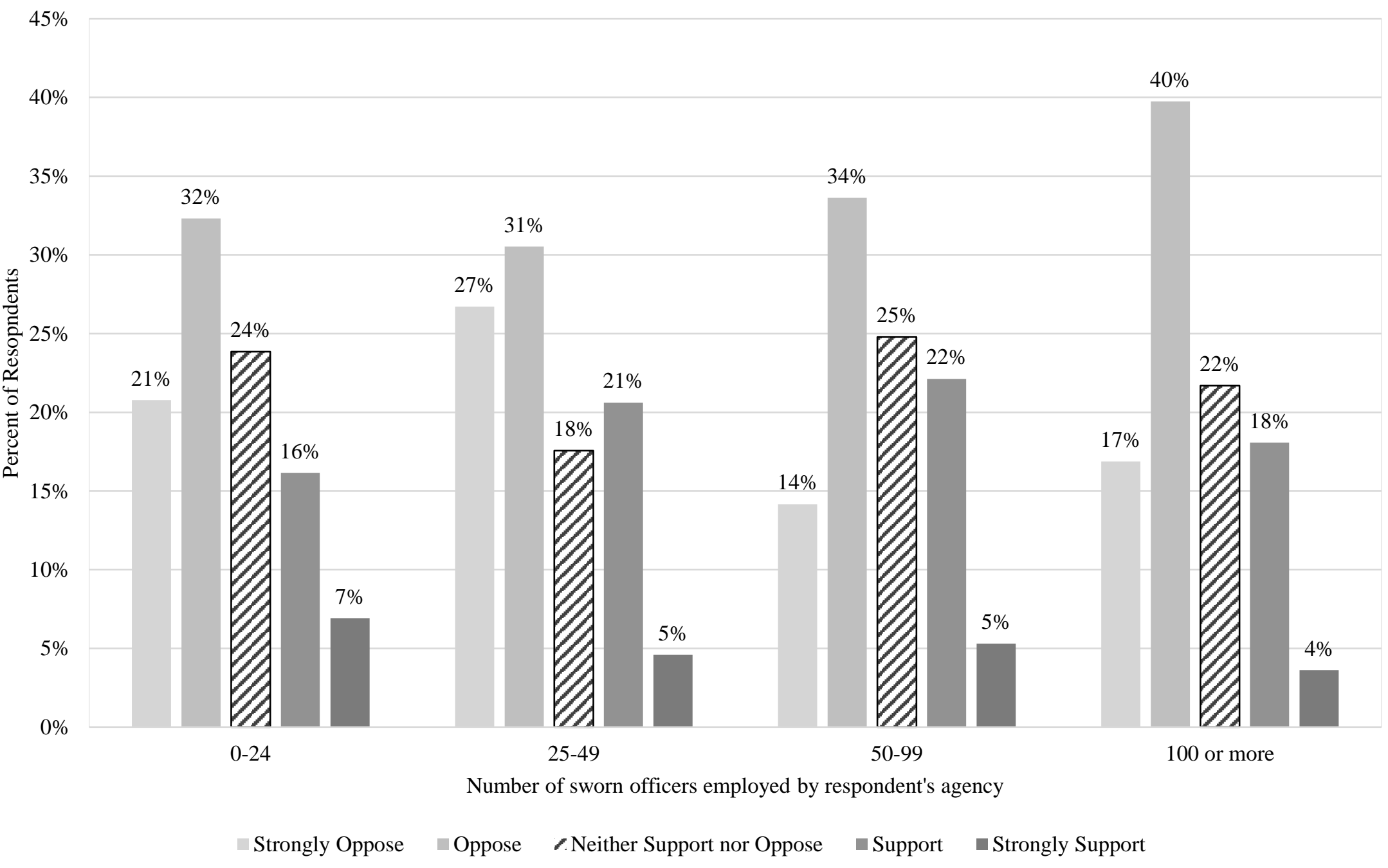

Pearson's $\chi^{2}=10.991(p=.530)$. From left to right, the $N$ s for each group are: $130,131,113,83$. 
Figure 2. Adjusted Predictions (with 95\% CIs) for Anticipated Hostility of Media Coverage.

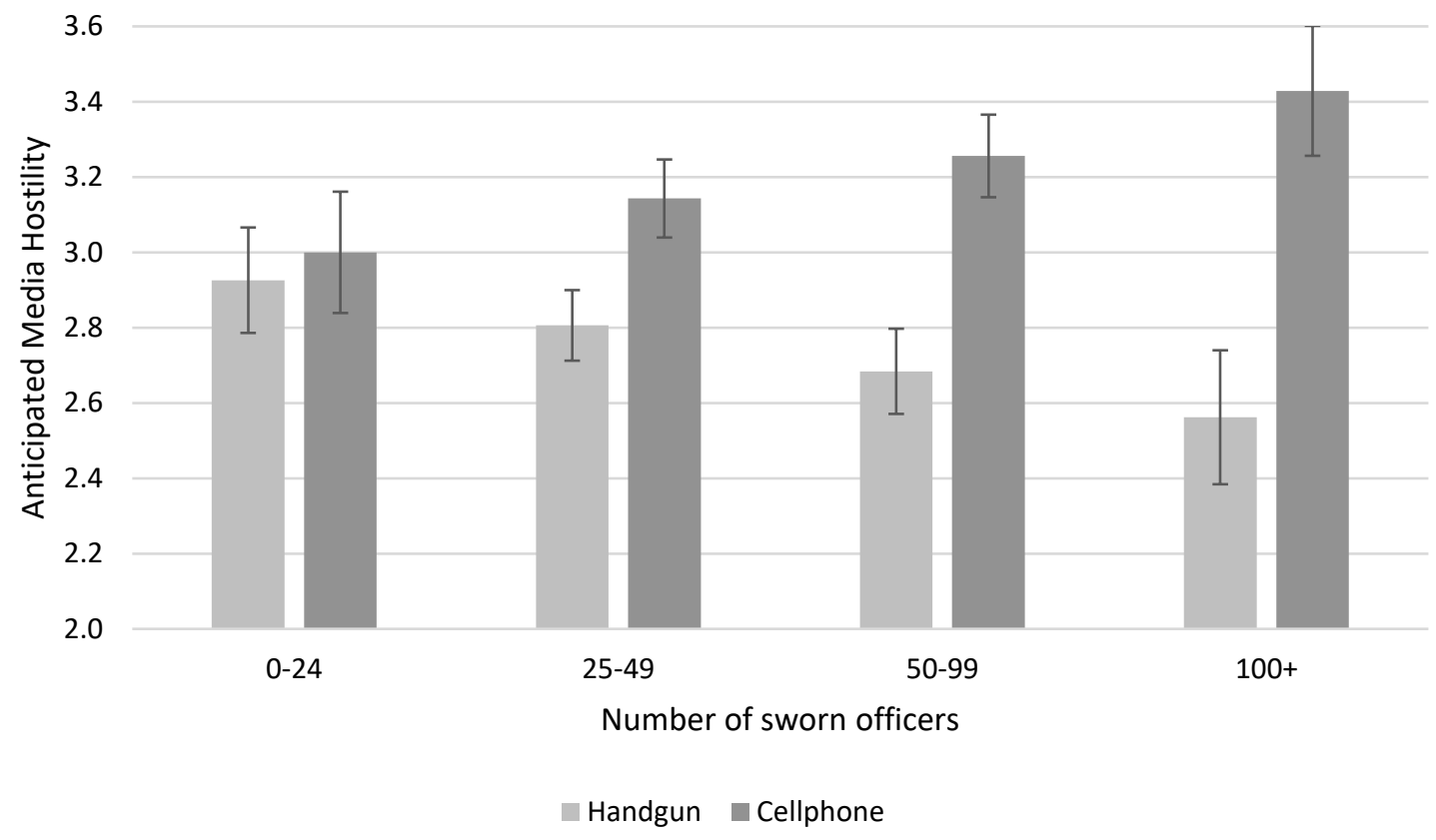

Note. $N=461$. 
Figure 3. Adjusted Predictions (with 95\% CIs) for Stating Publicly that the Shooting was Justified.

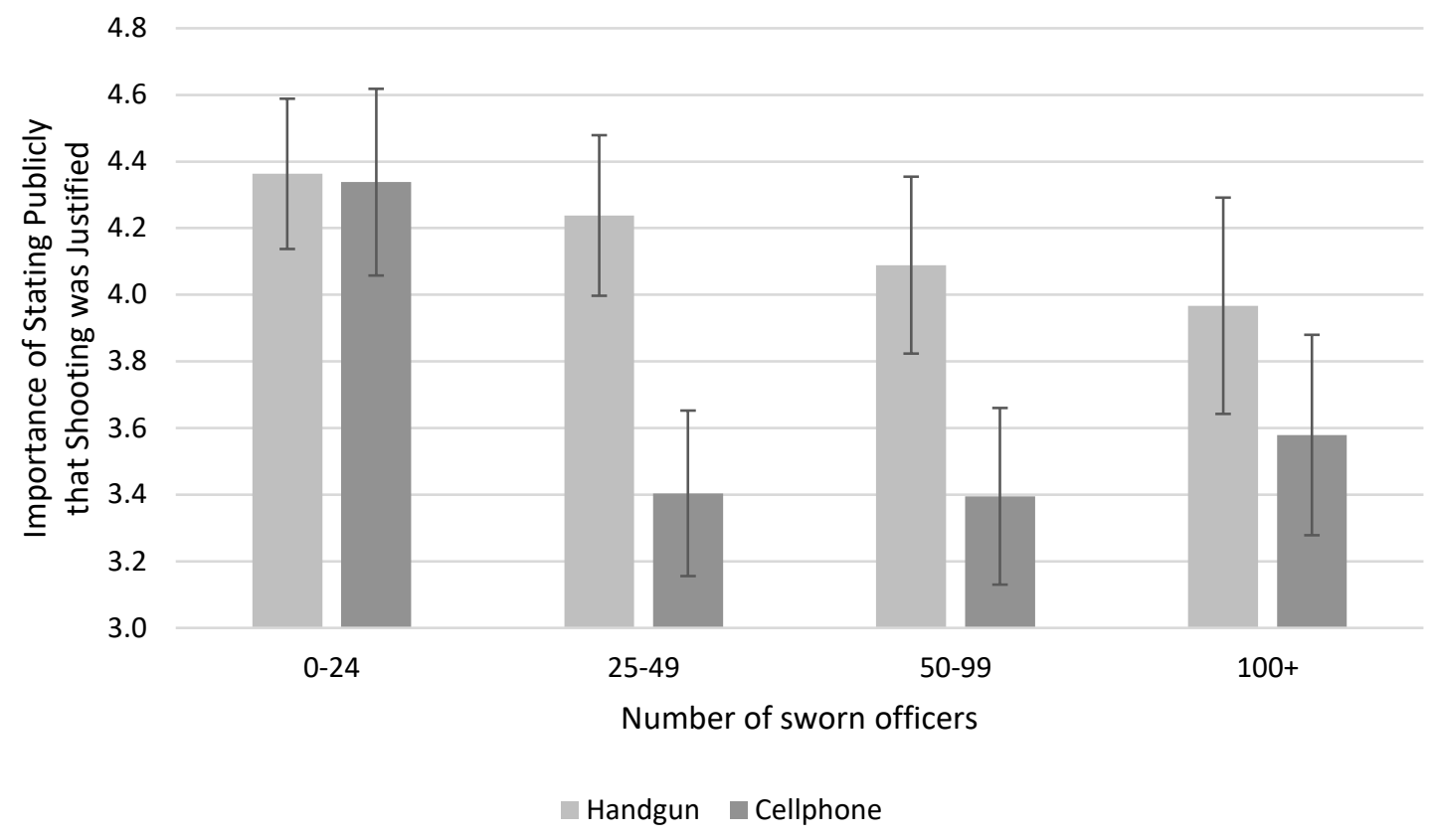

Note. $N=461$. 
Table 1. Effects of suspect race and armed/unarmed status on perceived media coverage and willingness to communicate with public, by agency size.

\begin{tabular}{|c|c|c|c|c|c|c|}
\hline \multirow[b]{3}{*}{ Experimental Manipulations } & \multicolumn{6}{|c|}{ Agency Size: 24 or fewer } \\
\hline & \multicolumn{2}{|c|}{$\begin{array}{c}\text { Model 1: } \\
\text { Anticipated Media } \\
(\mathrm{n}=131)\end{array}$} & \multicolumn{2}{|c|}{$\begin{array}{c}\text { Model 2: } \\
\text { State Justified } \\
(\mathrm{n}=130)\end{array}$} & \multicolumn{2}{|c|}{$\begin{array}{l}\text { Model 3: } \\
\text { Additional Communication } \\
(\mathrm{n}=130)\end{array}$} \\
\hline & $b$ & $p$-value & $b$ & $p$-value & $b$ & $p$-value \\
\hline Black suspect & .227 & .108 & .124 & .380 & .106 & .368 \\
\hline \multirow[t]{3}{*}{ Unarmed suspect } & .148 & .304 & -.035 & .810 & .222 & .066 \\
\hline & \multicolumn{6}{|c|}{ Agency Size: 25 - 49} \\
\hline & \multicolumn{2}{|c|}{$\begin{array}{c}\text { Model 4: } \\
\text { Anticipated Media } \\
(\mathrm{n}=133)\end{array}$} & \multicolumn{2}{|c|}{$\begin{array}{c}\text { Model 5: } \\
\text { State Justified } \\
(\mathrm{n}=134) \\
\end{array}$} & \multicolumn{2}{|c|}{$\begin{array}{l}\text { Model 6: } \\
\text { Additional Communication } \\
(\mathrm{n}=134)\end{array}$} \\
\hline Experimental Manipulations & $b$ & $p$-value & $b$ & $p$-value & $b$ & $p$-value \\
\hline Black suspect & .326 & .006 & .306 & .106 & .110 & .320 \\
\hline \multirow[t]{3}{*}{ Unarmed suspect } & .314 & .008 & -.836 & .000 & -.033 & .763 \\
\hline & \multicolumn{6}{|c|}{ Agency Size: 50 - 99} \\
\hline & \multicolumn{2}{|c|}{$\begin{array}{c}\text { Model 7: } \\
\text { Anticipated Media } \\
(\mathrm{n}=115)\end{array}$} & \multicolumn{2}{|c|}{$\begin{array}{c}\text { Model 8: } \\
\text { State Justified } \\
(\mathrm{n}=114) \\
\end{array}$} & \multicolumn{2}{|c|}{$\begin{array}{c}\text { Model 9: } \\
\text { Additional Communication } \\
(\mathrm{n}=115)\end{array}$} \\
\hline Experimental Manipulations & $b$ & $p$-value & $b$ & $p$-value & $b$ & $p$-value \\
\hline Black suspect & .229 & .093 & .207 & .288 & .207 & .061 \\
\hline \multirow[t]{3}{*}{ Unarmed suspect } & .427 & .002 & -.692 & .001 & -.069 & .528 \\
\hline & \multicolumn{6}{|c|}{ Agency Size: 100 or More } \\
\hline & \multicolumn{2}{|c|}{$\begin{array}{c}\text { Model 10: } \\
\text { Anticipated Media } \\
(\mathrm{n}=82)\end{array}$} & \multicolumn{2}{|c|}{$\begin{array}{c}\text { Model 11: } \\
\text { State Justified } \\
(\mathrm{n}=83)\end{array}$} & \multicolumn{2}{|c|}{$\begin{array}{l}\text { Model 12: } \\
\text { Additional Communication } \\
(\mathrm{n}=83)\end{array}$} \\
\hline Experimental Manipulations & $b$ & $p$-value & $b$ & $p$-value & $b$ & $p$-value \\
\hline Black suspect & -.223 & .000 & .279 & .286 & .069 & .606 \\
\hline Unarmed suspect & .942 & .117 & -.375 & .141 & -.012 & .925 \\
\hline
\end{tabular}


Table 2. Hypothesis testing results.

\begin{tabular}{lc}
\hline Hypothesis & Result \\
$\begin{array}{l}\text { (H1) Executives serving large agencies will be more supportive of } \\
\text { legislatively mandated transparency with the public following a } \\
\text { controversial BWC-captured OIS. }\end{array}$ & Not supported \\
$\begin{array}{l}\text { (H2) When controversial OIS caught on BWC involve Black } \\
\text { citizens, police executives will expect media coverage of the } \\
\text { incident to be more negative. }\end{array}$ & Partial Support \\
$\begin{array}{l}\text { (H3) A shooting involving a Black citizen captured on BWC will } \\
\text { likely affect the importance executives place on communicating } \\
\text { with the public. }\end{array}$ & Partial support \\
$\begin{array}{l}\text { (H4) Executives will expect media coverage of an OIS involving an } \\
\text { unarmed citizen to be more negative. }\end{array}$ & Partial Support \\
$\begin{array}{l}\text { (H5) Executives will be less supportive of communicating with the } \\
\text { public in the aftermath of an OIS involving an unarmed citizen. }\end{array}$ & Partial Support
\end{tabular}




\section{Supplemental Appendices}

Appendix A: Evidence that nonresponse bias is not a major concern

An anonymous reviewer raised concern that post-assignment attrition due to nonresponse bias was a threat to the internal validity of our experiment. As Shadish et al. (2002) emphasize, this is the one threat to internal validity that random assignment can do nothing about. Much of the recent work on dropping people who fail manipulation checks (Aronow et al., 2019), or otherwise conditioning on post-treatment variables (colliders; see e.g., Montgomery et al., 2019), focuses on how these practices amount to researcher-induced attrition and can annul random assignment if those post-treatment variables are correlated with other factors that affect outcomes. The reviewer is correct that nonresponse - if it was associated both with our treatment and other unmeasured variables that were correlated with our outcomes - would amount to a collider variable, and analyzing data only from those who responded to our survey would introduce attrition bias (Elwert and Winship, 2014). The directed acyclic graph (DAG) would resemble what is depicted in Figure A1. Fortunately, response rates for each experimental group were nearly identical, and the information presented in Tables A1-A2 show that the characteristics of our sample resemble those of the larger population from which it was drawn. The characteristics of respondents assigned to the different experimental conditions are also similar (Table A3).

Figure A1. Directed acyclic graph showing how nonresponse bias could threaten the internal validity of our experiment.

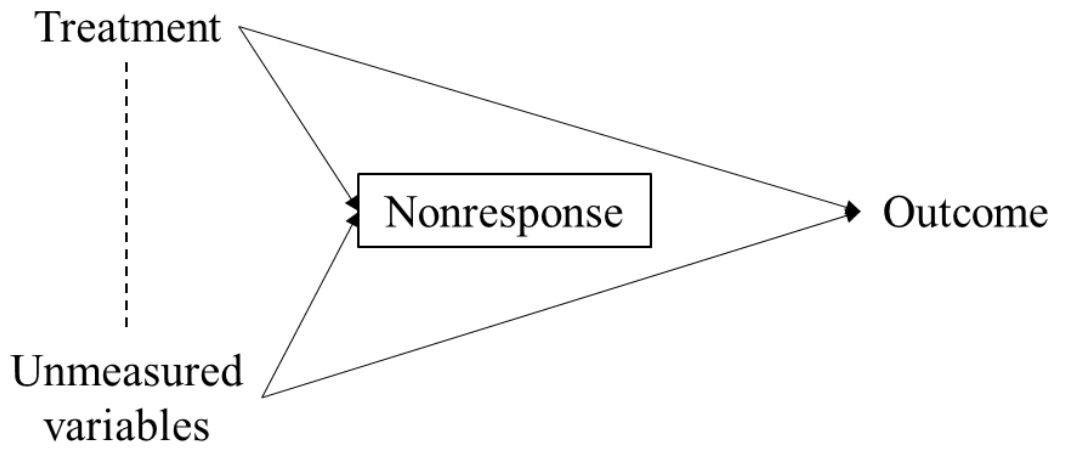


Table A1. Sample demographics v. Population of police executives.

\begin{tabular}{lcc}
\hline & Our Sample & Population $(2016)^{*}$ \\
\hline Race/Ethnicity & & \\
White & $91 \%$ & $90 \%$ \\
Black & $4 \%$ & $4 \%$ \\
Hispanic & $3 \%$ & $3 \%$ \\
Other & $2 \%$ & $2 \%$ \\
Gender & & \\
Male & $96 \%$ & $97 \%$ \\
Female & $4 \%$ & $3 \%$ \\
\hline
\end{tabular}

* Estimates from Hyland \& Davis (2019), which surveyed a stratified random sample of 2,612 local police departments and received an $82 \%$ response rate. Our sample mirrors this nationally representative sample in terms of executives' race/ethnicity and gender.

Table A2. Municipal agencies that currently have body-worn cameras (BWCs).

\begin{tabular}{|c|c|c|c|c|c|c|}
\hline \multirow[b]{2}{*}{ Stratum } & \multicolumn{4}{|c|}{ Our Sample } & \multicolumn{2}{|c|}{$\begin{array}{c}\text { LEMAS BWC } \\
\text { Supplement }(2016)^{a}\end{array}$} \\
\hline & $\%$ "Yes" & $95 \% \mathrm{CI}$ & $\begin{array}{c}\text { Estimated \# } \\
\text { of Agencies } \\
\text { using BWCs }\end{array}$ & $95 \% \mathrm{CI}$ & \% "Yes" & $\begin{array}{l}\text { Estimated \# } \\
\text { of Agencies } \\
\text { using BWCs }\end{array}$ \\
\hline $0-24$ & $46 \%$ & $38-54 \%$ & 4,131 & $3,405-4,856$ & $48 \%$ & 4,417 \\
\hline $25-49$ & $44 \%$ & $37-52 \%$ & 716 & $593-839$ & $42 \%$ & 671 \\
\hline $50-99$ & $49 \%$ & $42-57 \%$ & 412 & $347-477$ & $42 \%$ & 358 \\
\hline $100+$ & $64 \%$ & $57-71 \%$ & 419 & $371-466$ & $60 \%$ & 401 \\
\hline Overall b & $47 \%$ & $39-55 \%$ & 5,678 & $4,716-6,639$ & $48 \%$ & 5,847 \\
\hline
\end{tabular}

a Estimates from the 2016 LEMAS body-worn camera supplement, which surveyed a stratified sample of 4,976 agencies and received a 79\% response rate. As part of the survey from which the present study derives, we asked executives if their agencies were currently using BWCs. The percentage of respondents who answered yes on our survey closely aligns with the percentage who answered yes on the LEMAS BWC supplement.

${ }^{\mathrm{b}}$ Weighted to account for the sampling procedure, which oversampled larger agencies. 
Table A3. Treatment balance.

\begin{tabular}{|c|c|c|c|c|c|c|}
\hline \multirow[b]{2}{*}{ Respondent Characteristics } & \multicolumn{3}{|c|}{ Race Condition } & \multicolumn{3}{|c|}{ Armed Condition } \\
\hline & $\begin{array}{l}\text { White } \\
\text { Suspect }\end{array}$ & $\begin{array}{c}\text { Black } \\
\text { Suspect }\end{array}$ & $t$-test & $\begin{array}{l}\text { Armed } \\
\text { Suspect }\end{array}$ & $\begin{array}{l}\text { Unarmed } \\
\text { Suspect }\end{array}$ & $t$-test \\
\hline \multicolumn{7}{|l|}{ Gender } \\
\hline Male & $53.1 \%$ & $46.9 \%$ & \multirow{2}{*}{-1.13} & $52.9 \%$ & $47.1 \%$ & \multirow{2}{*}{-0.22} \\
\hline Female & $66.7 \%$ & $33.3 \%$ & & $55.6 \%$ & $44.4 \%$ & \\
\hline \multicolumn{7}{|l|}{ Race } \\
\hline White & $53.2 \%$ & $46.8 \%$ & \multirow{2}{*}{0.24} & $51.7 \%$ & $48.3 \%$ & \multirow{2}{*}{-1.73} \\
\hline Non-white & $51.2 \%$ & $48.8 \%$ & & $65.9 \%$ & $34.2 \%$ & \\
\hline \multicolumn{7}{|l|}{ Education } \\
\hline$\geq$ Master's Degree & $54.8 \%$ & $45.2 \%$ & \multirow{2}{*}{0.55} & $49.8 \%$ & $50.2 \%$ & \multirow{2}{*}{-1.10} \\
\hline$<$ Master's Degree & $52.2 \%$ & $47.8 \%$ & & $54.9 \%$ & $45.1 \%$ & \\
\hline \multicolumn{7}{|l|}{ Agency uses BWCs a } \\
\hline Yes & $54.2 \%$ & $45.8 \%$ & \multirow{2}{*}{0.35} & $50.7 \%$ & $49.3 \%$ & \multirow{2}{*}{-0.93} \\
\hline No & $52.4 \%$ & $47.6 \%$ & & $55.0 \%$ & $45.0 \%$ & \\
\hline Years of Experience (mean) & 29.08 & 30.74 & $-2.30^{*}$ & 29.82 & 29.90 & -0.12 \\
\hline
\end{tabular}

NOTE: Reviewers raised concerns that other variables (besides the treatment conditions) could be correlated with our outcomes. However, we randomly assigned respondents to treatment groups, thereby balancing (on expectation) these potentially relevant variables, as well as all others (both known and unknown) across treatment groups - thus obviating the need for statistical controls (Freedman, 2008). Although it is unnecessary to do so, including statistical controls could be counterproductive. Especially with small samples $(\mathrm{N}<500)$, including statistical controls in experimental analyses can bias findings, reduce asymptotic precision, and result in inaccurate measures of precision (Freedman, 2008; Berk et al., 2013). Fortunately, the figures above demonstrate that our treatment groups were balanced in terms of respondent gender, race, education, and whether the respondent's agency was currently using BWCs. The lone exception is years of experience in the race condition. In that condition, those who read the vignette involving a Black suspect had, on average, one additional year of experience than those who read the vignette involving the white suspect (30.74 v. 29.08, $t=-2.30, p=.02)$. Note, however, that years of experience was not significantly correlated with any of our outcomes: anticipated media $(r=.04, p=.39)$, state justified $(r=-.002, p=.97)$, and additional communication $(\mathrm{r}=.07, \mathrm{p}=.12)$. Thus, the fact that years of experience is not perfectly balanced across treatment groups is not a concern at all for the internal validity of our findings. Imbalance only matters when it is correlated with outcomes (Mutz, Permantle, \& Pham, 2019).

${ }^{*} p<.05 ;{ }^{\mathrm{a}}$ Unweighted frequency. 
Appendix B: Stratum-specific factor analyses for anticipated media coverage and additional communication outcomes

\section{Table B1. Results of stratum-specific factor analyses.}

\begin{tabular}{|c|c|c|c|c|}
\hline \multirow{2}{*}{ Scales [Survey Items] } & 0-24 Sworn & 25-49 Sworn & 50-99 Sworn & $100+$ Sworn \\
\hline & Loadings & Loadings & Loadings & Loadings \\
\hline \multicolumn{5}{|l|}{ Anticipated Media Coverage } \\
\hline [Positive or negative] & .801 & .755 & .727 & .830 \\
\hline [Fair or unfair] & .886 & .824 & .890 & .916 \\
\hline [Truthful or untruthful] & .858 & .850 & .862 & .847 \\
\hline [Reliable or unreliable] & .913 & .840 & .827 & .918 \\
\hline Eigenvalue & 3.000 & 2.677 & 2.747 & 3.087 \\
\hline Cronbach's Alpha & .922 & .892 & .899 & .926 \\
\hline \multicolumn{5}{|l|}{ Additional Communication } \\
\hline [Release the video to the public within 48 hours] & .523 & .365 & 617 & .503 \\
\hline [Release demographic information about the involved officer] & .486 & .237 & .624 & .447 \\
\hline $\begin{array}{l}\text { [Use social media to keep the community updated on the shooting as details } \\
\text { unfold] }\end{array}$ & .524 & .522 & .554 & .616 \\
\hline [Make a statement to the media regarding the shooting within 24 hours] & .560 & .720 & .476 & .377 \\
\hline [Send someone to meet with the suspect's family to discuss the incident] & .533 & 633 & .340 & .485 \\
\hline Eigenvalue & 1.382 & 1.381 & 1.418 & 1.210 \\
\hline Cronbach's Alpha & .666 & .606 & .647 & .597 \\
\hline
\end{tabular}

NOTE: In each stratum, all items loaded onto a single factor (Eigenvalue cutoff $=1.00$ ). The media items were perceived equally across groups, but there was more variation in how the additional communication items were perceived across groups. Importantly, our findings with respect to the additional communication outcome did not differ by stratum - so differences in how the items were perceived is unlikely to explain them. Future research on this topic might consider exploring alternative measures. 
Appendix C: Results using mean scales vs. weighted factor scores

Table C1. Comparison of OLS Estimates Using Mean Scales and Weighted Factor Scores.

\begin{tabular}{|c|c|c|c|c|}
\hline & \multicolumn{2}{|c|}{ Using Mean Scales } & \multicolumn{2}{|c|}{ Using Weighted Factors } \\
\hline & $b$ & $p$-value & $b$ & $p$-value \\
\hline \multicolumn{5}{|c|}{ DV: Anticipated Media } \\
\hline \multicolumn{5}{|c|}{ Model 1} \\
\hline Black suspect & .227 & .108 & .301 & .099 \\
\hline Unarmed suspect & .148 & .304 & .122 & .510 \\
\hline \multicolumn{5}{|l|}{ Model 4} \\
\hline Black suspect & .326 & .006 & .408 & .006 \\
\hline Unarmed suspect & .314 & .008 & .353 & .017 \\
\hline \multicolumn{5}{|l|}{ Model 7} \\
\hline Black suspect & .229 & .093 & .270 & .123 \\
\hline Unarmed suspect & .427 & .002 & .521 & .003 \\
\hline \multicolumn{5}{|l|}{ Model 10} \\
\hline Black suspect & -.223 & .000 & -.304 & .089 \\
\hline Unarmed suspect & .942 & .117 & 1.161 & .000 \\
\hline \multicolumn{5}{|c|}{ DV: Additional Communication } \\
\hline \multicolumn{5}{|c|}{ Model 3} \\
\hline Black suspect & .106 & .368 & .112 & .469 \\
\hline Unarmed suspect & .222 & .066 & .227 & .156 \\
\hline \multicolumn{5}{|l|}{ Model 6} \\
\hline Black suspect & .110 & .320 & .163 & .258 \\
\hline Unarmed suspect & -.033 & .763 & .013 & .927 \\
\hline \multicolumn{5}{|l|}{ Model 9} \\
\hline Black suspect & .207 & .061 & .272 & .045 \\
\hline Unarmed suspect & -.069 & .528 & -.084 & .530 \\
\hline \multicolumn{5}{|l|}{ Model 12} \\
\hline Black suspect & .069 & .606 & .109 & .487 \\
\hline Unarmed suspect & -.012 & .925 & .015 & .923 \\
\hline
\end{tabular}

NOTE: We constructed mean scales for these outcomes, rather than weighted factor scores, for three reasons. First, the advantage of averaging instead of adding items is that it retains respondents who have item missing values on only one of the included items (by averaging the items they did answer). Second, factor scores are highly dependent on the specific extraction and rotation methods used (DiStefano, Zhu, \& Mindrila, 2009; Grice, 2001). As Grice (2001: 441) explains: "for any single common factor, an infinite number of sets of scores can be derived that are equally consistent with the factor loadings. Under particular circumstances, competing sets of scores for the same factor can actually be orthogonal or negatively correlated, thus yielding completely different rankings of the individuals." By contrast, mean scores do not vary depending on the factor analytic method used, and always rank respondents in a specific way based only on the answers they gave. Put differently, mean scores are less sensitive to researcher degrees of freedom. Third, and most importantly, the above figures show that our results are substantively the same regardless of how we construct the indices. 
Appendix D: Results using OLS vs. ordered logistic regression on the state justified outcome

Table D1. Comparison of OLS v. OLogit estimates for State Fustified outcome.

\begin{tabular}{|c|c|c|c|c|}
\hline & \multicolumn{2}{|c|}{ OLS } & \multicolumn{2}{|c|}{ OLogit } \\
\hline & $b$ & $p$-value & $b$ & $p$-value \\
\hline \multicolumn{5}{|l|}{ Model 2} \\
\hline Black suspect & .124 & .380 & .410 & .227 \\
\hline Unarmed suspect & -.035 & .810 & -.114 & .742 \\
\hline \multicolumn{5}{|l|}{ Model 5} \\
\hline Black suspect & .306 & .106 & .430 & .179 \\
\hline Unarmed suspect & -.836 & .000 & -1.410 & .000 \\
\hline \multicolumn{5}{|l|}{ Model 8} \\
\hline Black suspect & .207 & .288 & .388 & .267 \\
\hline Unarmed suspect & -.692 & .001 & -1.307 & .000 \\
\hline \multicolumn{5}{|l|}{ Model 11} \\
\hline Black suspect & .279 & .286 & .470 & .281 \\
\hline Unarmed suspect & -.375 & .141 & -.635 & .136 \\
\hline \multicolumn{5}{|l|}{ Figure 3} \\
\hline Black suspect & .225 & .018 & .424 & .017 \\
\hline Unarmed suspect & -.025 & .888 & -.099 & .773 \\
\hline $25-49$ sworn & -.125 & .449 & -.223 & .476 \\
\hline 50-99 sworn & -.274 & .117 & -.473 & .156 \\
\hline $100+$ sworn & -.396 & .046 & -.738 & .044 \\
\hline Unarmed\#25-49 & -.809 & .001 & -1.369 & .004 \\
\hline Unarmed\#50-99 & -.669 & .011 & -1.223 & .012 \\
\hline Unarmed\#100+ & -.362 & .204 & -.594 & .263 \\
\hline
\end{tabular}

NOTE: An anonymous reviewer raised concern about using OLS with ordinal variables. This table shows that our results are not sensitive to the regression method used. We elected to retain the OLS models in the main text for three reasons. The first is ease of interpretation. Second, there is ongoing debate about whether linear modeling is more appropriate for experimental analyses like ours (see e.g., Gomila, 2019; Huang, 2019). Indeed, the use of OLS with categorical variables is quite common in the economics literature, where it is called a "linear probability model," and has been shown to be especially useful for experiments (see e.g., Huang, 2019). Third, randomization inference is valid regardless of the outcome distribution, as we note in the main text (Gerber \& Green, 2012; Keele et al., 2012). 
Appendix E: The non-moderating effects of community population and violent crime rate

Reviewers were concerned that our largest stratum (100+ officers) was more heterogenous than the other three strata in terms of the number of officers employed, and commented that other variables - such as urbanicity or social context - could moderate some of our key findings. Although the internal validity of our findings with respect to the effects of the experimental manipulations on our outcomes was never in doubt, the reviewers are correct that the moderating effects of agency size reported in Figures 2-3 of the main text could be spurious, reflecting the moderating effect of other variables such as urbanicity or social context. In Tables E1-E2, we re-estimated the models presented in Figures 2-3 of the main text - this time including interaction terms for Unarmed ${ }^{*}$ Population and Unarmed ${ }^{*}$ Violent Crime Rate. The results are substantively similar to those presented in the main text: Unarmed ${ }^{*} S w o r n$ is statistically significant, whereas the two new interaction terms are not. This suggests that something other than a jurisdiction's size or its violent crime rate likely explains the differences in our findings across strata - perhaps operating budget or past experience with officer-involved shootings, critical incidents, or other news-generating events. We do not have any of these measures, but implore researchers to consider them in future work on this topic.

Table E1. Interaction Effects of Unarmed ${ }^{*}$ Population and Unarmed ${ }^{*}$ Violent Crime Rate on Anticipated Media $(\mathrm{N}=397)$.

\begin{tabular}{lccc}
\hline Variable & $b$ & SE & $p$ \\
\hline Suspect Black & $.185^{*}$ & .073 & .011 \\
Suspect Unarmed & 1.258 & 1.239 & .311 \\
Sworn & $-.304^{* *}$ & .094 & .001 \\
Suspect Unarmed*Sworn & $.464^{* * *}$ & .138 & .001 \\
Population & .141 & .076 & .063 \\
Suspect Unarmed*Population & -.128 & .116 & .271 \\
Violent Crime Rate & .014 & .055 & .796 \\
Suspect Unarmed*Violent Crime Rate & -.018 & .083 & .826 \\
Intercept & $1.460^{*}$ & .787 & .064 \\
F-Test & & $7.653^{* * *}$ & \\
Adjusted $R^{2}$ & & .119 & \\
\hline
\end{tabular}

NOTE: Population and violent crime estimates were averaged from what was reported to the Uniform Crime Report in 2014, 2015, and 2016. Violent crime rate is the number of homicides, rapes, robberies, and aggravated assaults divided by the population and multiplied by 100,000. Both population and violent crime rate were highly skewed, so the variables used here represent their natural log transformations. Note that the $\mathrm{N}$ falls from 461 to 397 due to missing UCR data. 
Table E2. Interaction Effects of Unarmed ${ }^{*}$ Population and Unarmed ${ }^{*}$ Violent Crime Rate on State Fustified $(\mathrm{N}=397)$.

\begin{tabular}{lccc}
\hline Variable & $b$ & SE & $p$ \\
\hline Suspect Black & $.233^{*}$ & .104 & .025 \\
Suspect Unarmed & -1.336 & 1.786 & .455 \\
Sworn & & & \\
$25-49$ & .196 & .248 & .430 \\
$50-99$ & .261 & .311 & .402 \\
$100+$ & .229 & .426 & .592 \\
Suspect Unarmed ${ }^{*}$ Sworn & & & .004 \\
$25-49$ & $-1.086^{* *}$ & .372 & .023 \\
$50-99$ & $-1.074^{*}$ & .469 & .190 \\
100+ & -.820 & .625 & .064 \\
Population & -.207 & .111 & .426 \\
Suspect Unarmed ${ }^{*}$ Population & .136 & .170 & .663 \\
Violent Crime Rate & -.033 & .076 & .891 \\
Suspect Unarmed*Violent Crime Rate & .016 & .116 & .000 \\
Intercept & $6.347^{* * *}$ & 1.134 & \\
F-Test & & 6.153 & \\
Adjusted $R^{2}$ & & .135 & \\
\hline NOTE: Population and violent crime estimates were averaged from what was reported to the FBI's Uniform \\
Crime Report in 2014, 2015, and 2016. Violent crime rate is the number of homicides, rapes, robberies, and \\
aggravated assaults divided by the population and multiplied by 100,000. Both population and violent crime \\
rate were highly skewed, so the variables used here represent their natural log transformations. Note that the N \\
falls from 461 (in the main text) to 397 due to missing UCR data. \\
\end{tabular}

